\title{
Long-lived crustal damage zones associated with fault intersections in the high Andes of Central Chile
}

\author{
*José Piquer", , Gonzalo Yáñez ${ }^{3,6,7}$, Orlando Rivera ${ }^{4}$, David R. Cooke ${ }^{2,5}$ \\ ${ }^{I}$ Instituto de Ciencias de la Tierra, Universidad Austral de Chile, Edificio Pugín, Av. Eduardo Morales Miranda, Valdivia, Chile. \\ jose.piquer@uach.cl \\ 2 CODES, University of Tasmania, Private Bag 79, 7001, Hobart, Australia. \\ d.cooke@utas.edu.au \\ 3 Departamento de Ingeniería Estructural y Geotécnica, Pontificia Universidad Católica de Chile, Vicuña Mackenna 4860, Santiago, Chile. \\ gyanez@ing.puc.cl \\ 4 Exploraciones Mineras Andinas S.A., Apoquindo 4775, oficina 602, Santiago, Chile. \\ Current address: Minera Peñoles de Chile Ltda., Alonso de Córdova 5151, oficina 902, Santiago, Chile. \\ orlando_rivera@penoles.com.mx \\ 5 TMVC (Transforming the Mining Value Chain), an Australian Research Council Industrial Transformation Research Hub, University \\ of Tasmania, Private Bag 79, 7001, Hobart, Australia. \\ ${ }^{6}$ Centro de Excelencia en Geotermia de los Andes (CEGA), Plaza Ercilla 803, Santiago, Chile. \\ 7 Núcleo Milenio Trazadores de Metales (NMTM), Plaza Ercilla 803, Santiago, Chile. \\ *Corresponding author: jose.piquer@uach.cl
}

\begin{abstract}
Long-lived, high-angle fault systems constitute high-permeability zones that can localize the upward flow of hydrothermal fluids and magma throughout the upper crust. Intersections of these types of structures can develop complex interference patterns, which constitute volumes of damaged rock (networks of small-scale faults and fractures) where permeability may be significantly enhanced. This is relevant for understanding regional-scale structural controls on the emplacement of hydrothermal mineral deposits and volcanic centers, and also on the distribution of areas of active upper-crustal seismicity. In the high Andes of central Chile, regional-scale geophysical (magnetic, gravimetric, seismic) and structural datasets demonstrate that the architecture of this Andean segment is defined by NW- and NE-striking fault systems, oblique to the N-S trend of the magmatic arc. Fault systems with the same orientations are well developed in the basement of the Andes. The intersections of conjugate arc-oblique faults constitute the site of emplacement of Neogene intrusive complexes and giant porphyry $\mathrm{Cu}$-Mo deposits, and define the location of major clusters of uppercrustal earthquakes and active volcanic centers, suggesting that these fault systems are still being reactivated under the current stress regime. A proper identification of one-dimensional, lithospheric-scale high-permeability zones located at the intersections of high-angle, arc-transverse fault systems could be the key to understanding problems such as the structural controls on magmatic and hydrothermal activity and the patterns of upper-crustal seismicity in the high Andes and similar orogenic belts.
\end{abstract}


RESUMEN. Zonas de daño cortical de larga vida, asociadas con intersecciones estructurales en los altos Andes de Chile central. Los sistemas de falla de alto ángulo y de larga vida constituyen zonas de alta permeabilidad que pueden focalizar el flujo ascendente de fluidos hidrotermales y magma a través de la corteza superior. La intersección de estructuras de este tipo involucra el desarrollo de patrones de interferencia complejos, que constituyen volúmenes de roca dañada (redes de fallas y fracturas de pequeña escala) en las cuales la permeabilidad está particularmente incrementada. Esto es relevante para la comprensión tanto del control estructural regional sobre el emplazamiento de depósitos minerales y centros volcánicos, como de la distribución de áreas de sismicidad cortical activa. En los Andes de Chile central, estudios geofísicos de escala regional (magnetismo, gravimetría, sismicidad) y datos estructurales demuestran que la arquitectura de este segmento andino está definida por sistemas de falla con rumbos NW y NE, oblicuas al eje N-S del arco magmático. Sistemas de falla de la misma orientación están bien desarrollados en el basamento andino. La intersección de fallas conjugadas oblicuas al arco constituye el sitio de emplazamiento de complejos intrusivos neógenos y de pórfidos de Cu-Mo gigantes, y define la ubicación de agrupaciones mayores de sismos corticales y de centros volcánicos activos, lo cual sugiere que estos sistemas de falla continúan siendo reactivados bajo el régimen de esfuerzos actual. Una adecuada identificación de zonas unidimensionales de alta permeabilidad y de escala litosférica, ubicadas en la intersección de sistemas de falla de alto ángulo oblicuos al arco, puede ser clave para la comprensión de problemas como el control estructural de la actividad magmática e hidrotermal y los patrones de sismicidad cortical en los Andes y otros cinturones orogénicos similares.

Palabras clave: Intersección de fallas de basamento, Flujo de magmas y fluidos hidrotermales, Chile central.

\section{Introduction}

Major high-angle fault systems, under favorable combinations of fluid pressure and orientation relative to the prevailing stress tensor, can act as pathways for both magmas and hydrothermal fluids to rise through the crust, enabling them to control the location of different types of mineral deposits (e.g., Tosdal and Richards, 2001; Sillitoe, 2003; Amilibia et al., 2008; McCuaig and Hronsky, 2014) and volcanic systems (e.g., Cembrano and Lara, 2009; Tibaldi et al., 2017). Moreover, intersecting conjugate faults develop complex interference patterns characterized by fracturing and the growth of subsidiary faults, creating one-dimensional, highly-permeable damage zones (Horsfield, 1980; Hodgson, 1989; Schwarz and Kilfitt, 2008). However, there are several mineral districts or belts where the emplacement of magmatic-hydrothermal centers is not related to any obvious, major fault system (e.g., Perelló et al., 2003; Sillitoe and Perelló, 2005; Mpodozis and Cornejo, 2012; Leveille and Stegen, 2012), posing an important challenge for the development of conceptual exploration models. The Mio-Pliocene metallogenic belt of the high Andes of central Chile is one such example (e.g., Mpodozis and Cornejo, 2012). It contains the world's largest exploitable concentrations of $\mathrm{Cu}$ and Mo in two giant porphyry copper deposits: Río Blanco-Los Bronces and El Teniente (e.g., Sillitoe, 2010). The ore deposits are hosted by Cenozoic volcanic and intrusive rocks, which define a late Eocene to early Pliocene magmatic arc characterized by the opening and subsequent inversion of the intra-arc Abanico Basin (Godoy et al., 1999; Charrier et al., 2002). The volcanic stratigraphy has traditionally been divided into four main successions (Fig. 1): the northern part of the belt is characterized by the syn-extensional Abanico Formation (late Eocene to early Miocene) and the syn-inversion Farellones Formation (early to late Miocene; Aguirre, 1960; Klohn, 1960; Charrier et al., 2002; Piquer et al., 2017), while to the south most of the high Andes of central Chile are composed of the syn-extensional Coya-Machalí Formation (early to middle Miocene; Klohn, 1960; Piquer et al., 2017) and the syn-inversion Teniente Volcanic Complex (middle to late Miocene; Godoy, 1993; Kay et al., 2005; Piquer et al., 2017).

Segments of the inverted basin-margin faults have been documented (Charrier et al., 2002; Fuentes et al., 2002; Fock, 2005; Farías et al., 2010), and the internal architecture of the inverted basin was refined by Piquer et al. (2016). While the inverted basin-margin faults correspond to segmented, $\mathrm{N}$-striking faults parallel to the continental margin, the faults controlling the internal segmentation of the inverted basin are oblique to the axis of the magmatic arc (Fig. 1), their surface expression is less evident and have been interpreted as basement faults reactivated during the Cenozoic (Piquer et al., 2016). Most of the syn-inversion plutonic bodies (early to late Miocene) and in particular the 
mineral deposits and their associated subvolcanic complexes (late Miocene-early Pliocene) were emplaced in the central part of the inverted basin (Fig. 1); consequently, understanding the relationships between magmatism, hydrothermal activity and large-scale fault systems within the inverted basin is of critical importance. Here we use recently-acquired and pre-existing geophysical datasets, including upper-crustal seismicity and regional-scale gravimetry and magnetometry, to complement the structural data presented by Piquer et al. (2016) and new field data collected during 2016-2017. The combination of these independent datasets allows us to propose a regional-scale structural model which can explain the distribution of porphyry $\mathrm{Cu}-\mathrm{Mo}$ deposits, active volcanoes, uppercrustal seismicity, and the regional-scale patterns observed in gravimetric and magnetic maps. The proposed structural model has implications for the interpretation of structural controls on magmatism in other segments of the high Andes, as well as in other active or fossil orogenic belts globally.

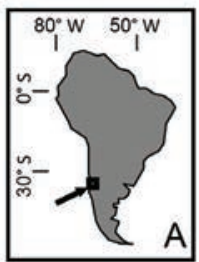

- Chile-Argentina border

Map B

- Cross sections
- Faults
Miocene-early Pliocene intrusions
Teniente Volcanic Complex
Farellones Formation
Coya-Machali Formation
Abanico Formation
Mesozoic sedimentary and volcanic
Map C
Faults
— Reverse
— Dextral
- Sinistral
- Uncertain
— Miocene-early Pliocene intrusions
ॠ Porphyry Cu-Mo deposits
¿ Quaternary volcano

A Quaternary volcano

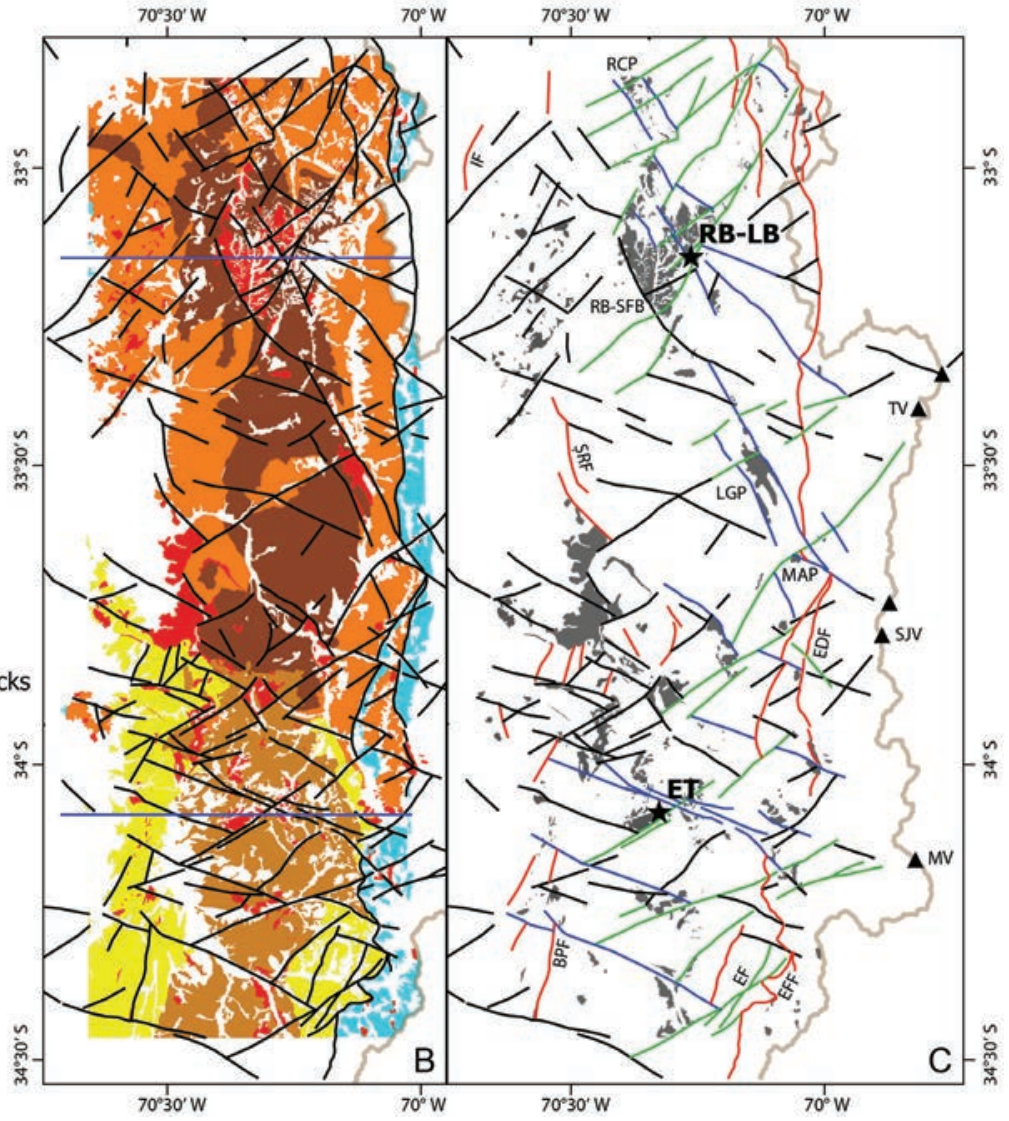

FIG. 1. A. Location of the study area in South America. B. Geology of the Andes of central Chile, based on Rivera and Cembrano (2000), SERNAGEOMIN (2002), Fuentes et al. (2004), Fock (2005) and this work. Quaternary sediments and volcanic deposits not shown. C. Main arc-oblique and arc-parallel fault systems, interpreted from mapped faults shown in B. Each fault system is colored according to its predominant sense of movement during the Miocene-early Pliocene. The figure also illustrates the correlation between the structural architecture of the inverted Abanico Basin, the emplacement of Mio-Pliocene plutons and mineral deposits and the location of active volcanoes. RB-LB: Río Blanco-Los Bronces; ET: El Teniente; RCP: Río Colorado pluton; RB-SFB: Río Blanco-San Francisco batholith; LGP: La Gloria pluton; MAP: Meson Alto pluton; TV: Tupungatito Volcano; SJV: San José Volcano; MV: Maipo Volcano; IF: Infiernillo fault; SRF: San Ramón fault; EDF: El Diablo fault; BPF: Barahona-Perales fault system; EF: Espinoza fault; EFF: El Fierro fault. 


\section{Structural geology of the High Andes of Central Chile}

Structural mapping of this Andean segment shows that within the inverted Abanico Basin, faults show preferred NW and NE strikes $\left( \pm 25^{\circ}\right.$; Fig. 1). Stratigraphic correlation across major faults indicates up to several hundred meters of normal displacement, with evidence of syn-tectonic deposition of the volcanic sequences (Piquer et al., 2015). Normal faulting has affected late Eocene-Oligocene rocks of the Abanico Formation (Fig. 2A) and locally early Miocene rocks of the lower part of the Farellones Formation (e.g., Fig. 2B), suggesting that the first pulse of deformation, responsible for widespread progressive unconformities found between the Abanico and Farellones Formations, was followed by a period of renewed extension, at least locally. However, kinematic indicators in individual fault planes, given by syn-tectonic hydrothermal minerals, commonly show strike-slip movements with variable amounts of reverse component (Fig. 2C; Piquer et al., 2016), indicating that several normal faults were subsequently reactivated with kinematics consistent with broadly E-directed compression (Piquer et al., 2016). Consistently, sense of movement is preferably dextral in NE faults and sinistral in NW faults (Fig. 2C). The strike-slip displacement is small, usually on the order of meters to tens of meters for an individual fault. The syn-tectonic hydrothermal minerals used as kinematic indicators (fault steps in epidote, tourmaline, quartz, calcite, chlorite, biotite and muscovite; Piquer et al., 2016; Fig. 2C) form part of different hydrothermal systems with a total age range of 14 to $4 \mathrm{Ma}$ (Maksaev et al., 2004; Toro et al., 2012; Deckart et al., 2013; Piquer et al., 2016), thus constraining the age of fault reactivation.
The Cenozoic kinematic evolution of arc-oblique fault systems described involved transtensional deformation during the late Eocene-early Miocene, and transpressional faulting during the middle Miocene-early Pliocene. This is consistent with previous interpretations of the kinematic history of arc-parallel (broadly N-striking) basin-margin faults, such as the El Fierro, Espinoza and El Diablo faults which define the eastern basin margin (Charrier et al., 2002; Fock, 2005; Piquer et al., 2010) and the San Ramón, Infiernillo and Barahona-Perales faults, defining the western margin (Fuentes et al., 2002; Fock, 2005; Rivera, 2017). In all of the previous cases, authors have interpreted an early (Paleogene) normal fault movement, indicated by syn-extensional growth strata and stratigraphic correlations, while a later (Neogene) reactivation in reverse mode is indicated by drag folds and syn-compression growth strata observed in fault-related folds.

In the eastern part of the inverted Abanico Basin, NW- and SW-dipping, arc-oblique faults commonly bound structural blocks with contrasting deformation styles (Fig. 2B, D, E). Towards the central part of the former basin, the hanging wall blocks contain younger, mostly flat-lying rocks that have been affected by local ramp-flat thrusts (e.g., Piquer et al., 2015). Towards the east, in turn, the footwall Cenozoic volcanic rocks are older and tightly folded. They have been affected by the thin-skinned deformation which characterizes the Aconcagua fold and thrust belt on the eastern flank of the Andes in Argentina (e.g., Giambiagi et al., 2003).

Major oblique structures are intimately related with the location and geometry of Miocene-early Pliocene intrusive bodies (Fig. 1C). Plutons were emplaced along major fault systems, and the individual plutonic facies are either strongly elongated with their major

FIG. 2. Field photographs illustrating different aspects of the arc-oblique fault systems which affect Cenozoic volcanic rocks in the Andes of central Chile. A. WNW-striking, S-dipping normal fault affecting pyroclastic and sedimentary deposits of Abanico Formation at $373809 \mathrm{mE}, 6310183 \mathrm{mN}$. The fault is part of a WNW system of normal faults without evidence of subsequent reverse or strike-slip reactivation. B. View SW from $393700 \mathrm{mE}, 6266260 \mathrm{mN}$, looking along strike of the NE-striking, NWdipping fault system to which the fault plane of $\mathrm{C}$ belongs. The structure juxtaposes strongly folded, Oligocene Abanico Formation rocks in the footwall with flat-lying, Early Miocene Farellones Formation rocks in the hanging wall. Black lines highlight bedding surfaces. Ages from Baeza (1999), Charrier et al. (2002) and Fock (2005). C. Syn-tectonic crystallization of tourmaline in a NE-striking, NW-dipping fault plane, with steps in mineral fibers indicating dextral strike-slip movement. Yellow arrow indicates the sense of movement of the missing block. Picture taken at $387888 \mathrm{mE}, 6255000 \mathrm{mN}$. D. Strongly folded early to middle Miocene volcanic and sedimentary rocks, which occur within wedges formed between the N-striking thrust faults at the inverted eastern margin of the Abanico Basin and NW- and NE-striking fault systems acting as conjugate strike-slip faults. View S from $387050 \mathrm{mE}, 6192200 \mathrm{mN}$. E. To the west of D, flat-lying middle Miocene rocks, typical of the central part of the inverted Abanico Basin. View SSW from 370500mE, 6201900mN. 

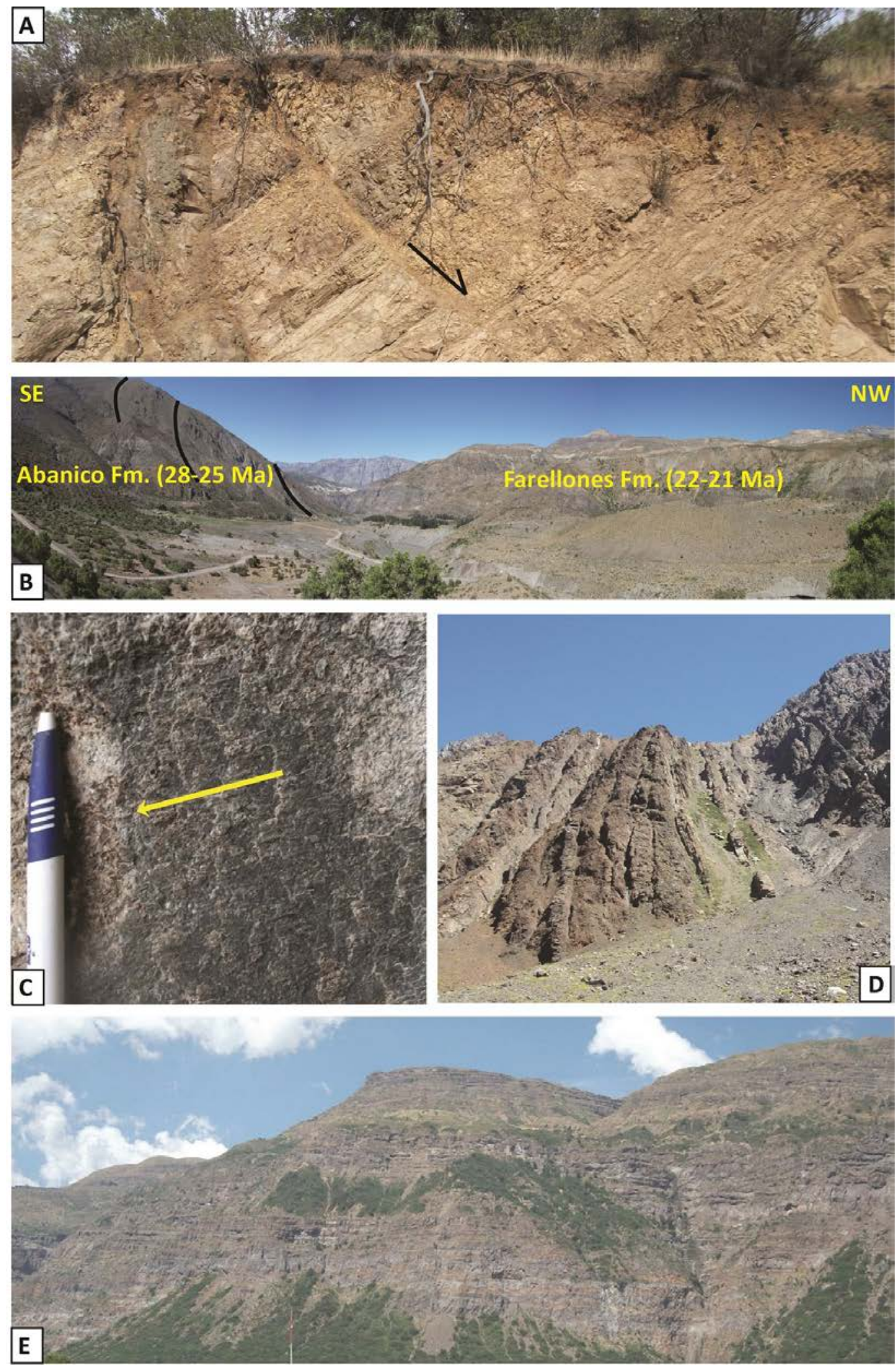
axis following the fault trend, or have rhombic shapes with their margins defined by intersecting NW- and NE-striking faults (Fig. 1C). In particular, the two porphyry copper deposits contained in this segment were emplaced at the intersections of NW- and NEstriking fault systems, acting as conjugate faults at the moment of mineral deposit emplacement (Fig. 1C; Piquer et al., 2016).

\section{Geophysics}

Regional geophysical information has been gathered in the study area from different sources, qualities and resolution over the last 30 years. Relevant to this study are the crustal seismicity, gravity and magnetic data. Crustal seismicity is a key parameter given the fact that deformation within the inverted Abanico Basin remains active today, whereas gravity and magnetic signals are complementary tools that can be used to define major lithological and structural domains.

\subsection{Seismicity}

Within the last 20 m.y., the Andes of Central Chile and Argentina have experienced $\sim 100 \mathrm{~km}$ of shortening (Farías et al., 2010), corresponding to a deformation rate on the order of $5 \mathrm{~mm} /$ year. This permanent deformation is about $5-7 \%$ of the convergence rate between the Nazca and South American plates, and produces active crustal seismicity and sporadically some large intraplate earthquakes, such as the Las Melosas $1958 \mathrm{Mw} 6.9$ earthquake (Sepúlveda et al., 2008; Alvarado et al., 2009; Fig. 3A). Instrumental information at teleseismic distance is available for the last 50 years (National Earthquake Information Centre, errors in the range of $10 / 20 \mathrm{~km}$ in the horizontal/vertical direction and completeness above $3 \mathrm{Mw}$ ). In addition, two local networks (CHASE 2005, Pardo et al., 2008; ANILLO 2006-2008, Farías et al., 2010), provide a representative data set that characterizes the active deformation of the crust in the study area. In these local databases completeness is above $2.5 \mathrm{Mw}$ with errors in the range of 5-10/8-15 km in horizontal/ vertical direction. Time windows of 40 years and 4 years for the regional and local networks respectively, ensure that enough small seismic events have been recorded to characterize crustal deformation, because the mean deformation rate is about $5 \mathrm{~mm} / \mathrm{yr}$ and relatively large intraplate earthquakes $(\sim 6.5 \mathrm{Mw})$ occur every $\sim 25$ years. Figure $3 \mathrm{~A}$ shows the total crustal seismicity over the structural network of the study area, with a depth cut-off at $20 \mathrm{~km}$. Figure 4 shows the hypocenter distribution along two cross-sections, passing through the porphyry $\mathrm{Cu}-\mathrm{Mo}$ deposits (Río Blanco-Los Bronces and El Teniente). The seismic events suspected to be associated with the mining operations were eliminated. Although errors involved in the location of individual earthquakes can be significant, even at the regional scale discussed in this work, the spatial trends of large numbers of events (clustering, alignments) and their correlation with the regional-scale structural architecture are highly relevant for understanding the structural controls on active deformation within the study area. Seismicity is mostly concentrated in the $\mathrm{N}$-striking eastern border of the former Abanico basin, in particular in the southern segment. However, clustering of seismic events and both NE and NW trends are observed in the central and western parts of the inverted Abanico Basin, some of them spatially correlated with the location of the Río Blanco-Los Bronces and El Teniente deposits (Figs. 3A, 4). These seismic clusters and alignments are strongly concentrated along regional-scale oblique structures, particularly at their intersections (Fig. 3A).

\subsection{Gravimetry}

Gravity data have being gathered within the framework of the Ring Project ACT Nº18 (Yáñez et al., 2008). This is a regional data set with stations at an average sampling distance of $5 \mathrm{~km}$, with differential GPS height control and errors on the order of $0.3 \mathrm{mGal}$. The residual gravity field for the study area is shown in figure $3 \mathrm{~B}$, along with the structural network and crustal seismicity. Residual gravity anomalies are referred to a "normal" crustal density of $2.7 \mathrm{gr} / \mathrm{cc}$, thus positive/negative anomalies implies crustal densities above/below $2.7 \mathrm{gr} / \mathrm{cc}$, respectively. The exact location of these anomalous crustal blocks require a formal modeling effort which is beyond the semi-quantitative approach of the present paper. A simple interpretation of the gravimetric data set shows that the strongest deformation of the Cenozoic volcanic rocks, observed in the structural geology and seismicity record, is spatially correlated with a gradient between medium and low density domains on the eastern flank of the area. In the southern part, this gradient is N-oriented and follows the eastern 
margin of the Abanico Basin. Towards the north, this transition zone acquires a NW trend, parallel to the NW-striking faults which traverse the Río BlancoLos Bronces district (Fig. 3B). Both porphyry Cu-Mo deposits (Río Blanco-Los Bronces and El Teniente) are located at the center of negative gravimetric anomalies. Although in absolute terms the associated negative anomaly is more intense in the case of Río Blanco-Los Bronces deposit compared to El Teniente, the difference is due to the closer proximity with a dense block to the west of El Teniente deposit, thus the positive anomaly associated with this dense block rises the background level towards the El Teniente deposit domain. The mass deficiency in both deposits might be due to a combination of two factors: the presence of large intermediate to felsic batholiths at depth, which are less dense than the surrounding basement rocks, and the intense fracturing and fluid flow associated with major structural intersection zones, which reduces the overall density of the rock mass. In the western part of the study area, long wavelength positive anomalies not fully covered by the data set used in this paper, suggest the presence of dense and deep crustal blocks. Previous studies (Yáñez and Rivera, 2009; Rivera and Cerda, 2012) have suggested a relationship between these dense blocks and the emplacement of nearby giant copper deposits, and according to modeling the depth to the roof of the dense body is in the range of 8-12 km (Yáñez et al., 2008; Yáñez and Rivera, 2009).

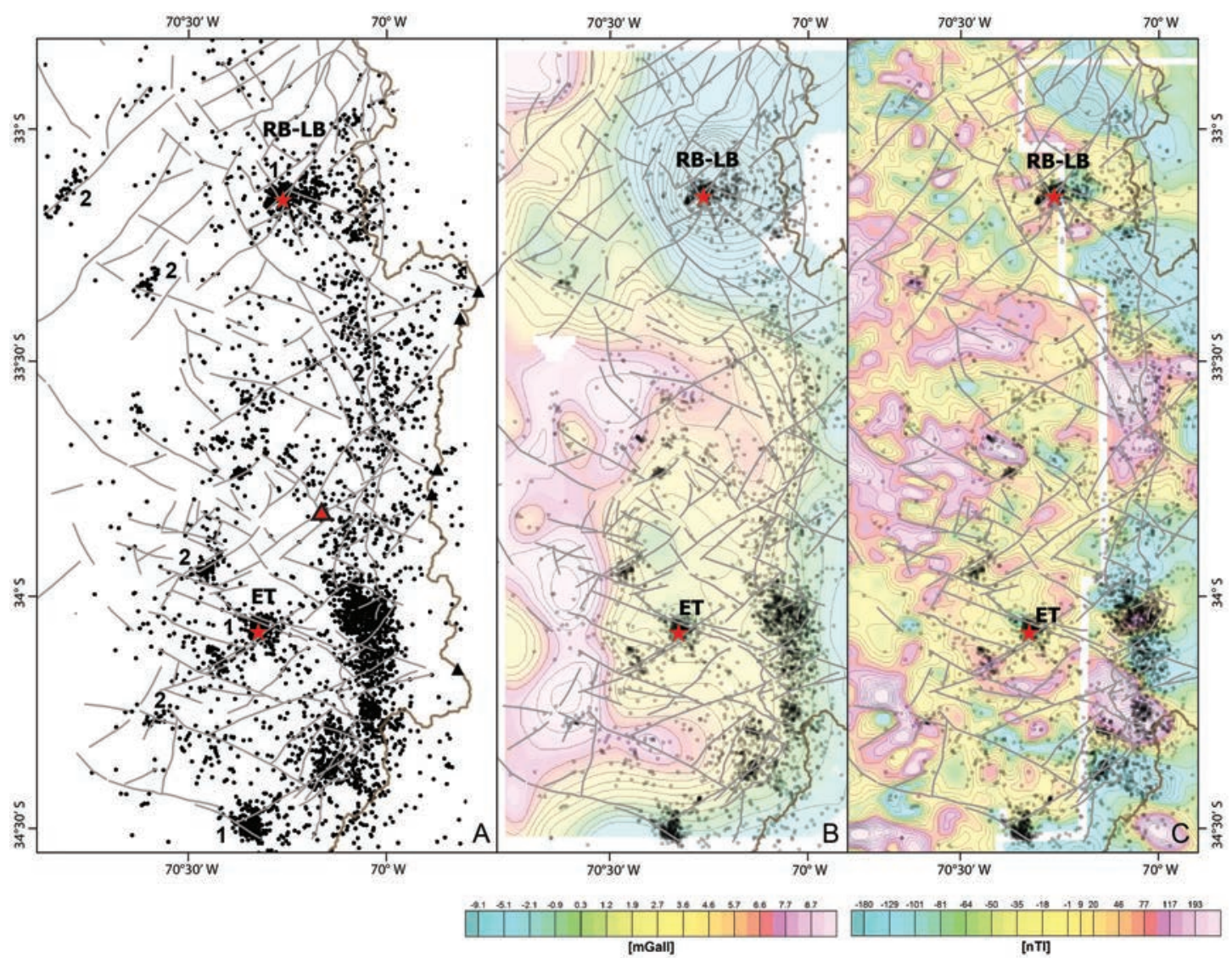

FIG. 3. Main arc-oblique and arc-parallel fault systems (from Fig. 1C) plotted against different regional geophysical data: A. Shallow hypocenters. Red triangle marks the location of the Las Melosas $1958 \mathrm{Mw} 6.9$ earthquake, and black triangles show the position of active volcanoes. 1. seismic clusters at fault intersections; 2. seismic alignments along arc-oblique faults. B. Shallow hypocenters and gravity field. C. Shallow hypocenters and the reduced to pole magnetic field. The two different surveys mentioned in the text are delimited by a narrow mask zone in order to clarify which domain belongs to each survey. RB-LB: Río Blanco-Los Bronces Cu-Mo deposit; ET: El Teniente Cu-Mo deposit. 


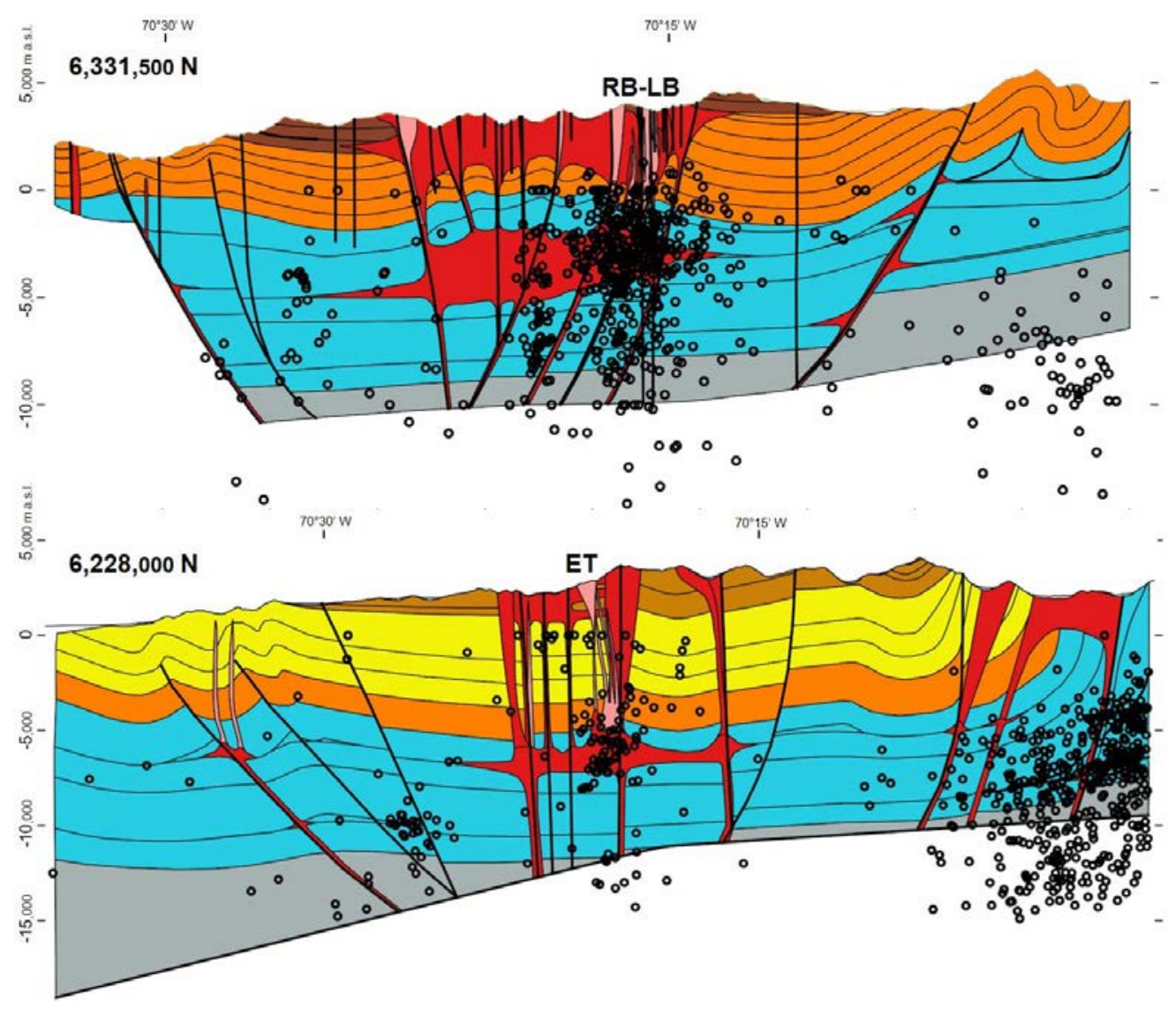

FIG. 4. Representative cross-sections of the study area. Location and legend shown in figure 1B. At the cross-sections, the pre-Mesozoic basement is shown in grey, and the porphyry Cu-Mo-related complexes of porphyritic stocks and hydrothermal breccias are highlighted in pink.

\subsection{Magnetometry}

The regional magnetic field of the western part of the study area was surveyed in the early 1980 s by the Chilean Geological Survey. The eastern part was surveyed in the early 1990s by CODELCO. Even though the technical conditions at the time of the two surveys were less robust than nowadays (i.e., pre GPS era for the western survey and without the appropriate aircraft for high altitude surveys on the eastern side), the data quality are good enough for the purposes of the present study. Both surveys were flown along $\mathrm{N}-\mathrm{S}$ flight lines, with line separation between 600 $1000 \mathrm{~m}$ and a clearance of 600-1,500 m. Figure 3C shows the reduced to the pole magnetic field of the study area, overlain by the structural network and crustal seismicity. The magnetic data highlights the major oblique structural trends much better than the gravity data, due in part to better resolution and also to line orientations (N-S) at high angles with respect to the structural pattern. Despite the low resolution of the magnetic data set, the magnetic fabric of the region (Fig. 3C) is consistent with the structural architecture of the study area (Fig. 1), in particular the NW and NE lineaments.

\section{Fault intersections, damage and permeability}

Structural and geophysical patterns confirm that the internal architecture of the inverted Abanico Basin is dominated by regional-scale faults oblique to the Andean belt and to the axis of the magmatic arc. These NW- and NE-striking faults were active both during the extensional period as normal faults, and then as conjugate strike-slip faults during tectonic inversion (Figs. 1, 2). As illustrated by figure 1C, 
the damage zones at the intersections of conjugate strike-slip faults were a highly favorable geometric location for the rise and emplacement of Miocene magmatic bodies, some of them precursors of late Miocene-early Pliocene porphyry $\mathrm{Cu}-\mathrm{Mo}$ deposits. Both known porphyry Cu-Mo clusters (Río BlancoLos Bronces and El Teniente), are located at the intersection zone of regional-scale fault systems, acting as conjugate strike-slip faults at the time of mineral deposit emplacement (Fig. 1C). Gravity data (Fig. 3B) shows that these highly permeable domains, the locus of large deposit emplacement, are located over negative to neutral gravity anomalies, in agreement with the expected physical nature of damage zones and large, differentiated upper-crustal magma chambers (reduced density relative to more intact basement rock).

As shown in figure 1C, Plio-Quaternary volcanic centers are also located along strike of major arcoblique fault systems. In fact, the alignment of eruptive vents in individual stratovolcanoes shows a very good correlation with the strike of regionalscale faults controlling the location of the volcanic complexes (Figs. 1C, 5). The Tupungato-Tupungatito complex is built over a major NE-striking, NWdipping dextral strike-slip fault system, which show evidence of earlier normal movement. The alignment of the main volcanic centers follows this same NE trend (Fig. 5A). In the case of the San José volcanic complex, individual craters are aligned along NNW and NW trends (Fig. 5B), parallel to a major fault system that can be followed from the volcanic complex to the NNW, and which appear to have controlled the emplacement of the Mesón Alto and La Gloria plutons, the Río Blanco-San Francisco batholith, the Río Colorado pluton and the Río Blanco-Los Bronces porphyry $\mathrm{Cu}-\mathrm{Mo}$ deposit (Fig. 1C). The Maipo volcano, in turn, has two main craters aligned along a WNW trend (Fig. $5 \mathrm{C})$, parallel to a regional-scale fault system which can be followed across the entire inverted Abanico Basin and which is at least spatially related to the El Teniente porphyry Cu-Mo deposit (Fig. 1C). This confirms the relevance of arc-oblique fault systems as pathways for the ascent of magmas and magmatic-derived hydrothermal fluids in the high Andes of central Chile. A similar conclusion has been reached by previous authors in the Andes of southern Chile (Cembrano and Lara, 2009; Sielfeld et al., 2017; Pérez-Flores et al., 2016).
Similarly, previous workers have demonstrated the strong control exerted by active faults in the circulation of hydrothermal fluids in active geothermal systems of southern Chile (e.g., Sánchez et al., 2013). However, there are no specific studies addressing this issue in central Chile. Figure 6 show the distribution of thermal springs in central Chile over the structural architecture of the study area. Thermal springs located close to the eastern margin of the Abanico Basin or in the Eastern Main Cordillera are in some cases associated with fumaroles and show chemical characteristics typical of thermal waters discharge around active volcanoes (Benavente et al., 2012). In contrast, those located near the western margin of the Abanico Basin or in the Coastal Cordillera correspond to low-temperature waters whose chemistry indicate interaction with meteoric waters during transport along faults (Benavente et al., 2012). The distribution of thermal springs (Fig. 6) suggests a strong correlation between fault architecture, fluid flow and the location of active hydrothermal cells. Most of the thermal occurrences are located over the trace of arc-oblique fault systems, commonly at their intersections with the inverted basin-margin faults of the Abanico Basin or at the intersections of pairs of arc-oblique faults.

The distribution of upper-crustal seismicity in central Chile (Fig. 3A) shows that most fault ruptures occur at the eastern inverted margin of the basin, particularly at the southern part of the study area. In general, little activity is observed at the inverted western basin margin. However, localized clusters of seismic activity are observed in the central and western parts of the inverted Abanico Basin, unrelated to the eastern basin margin faults. Their distribution shows a strong correlation with the intersections of regional-scale, arc-oblique fault systems (Fig. 3A), suggesting that these types of structures are also active and accommodate a relevant part of the permanent deformation of the South American margin. The largest crustal-related seismic event recorded in the region, the 1958 6.9 Mw Las Melosas event, shows a focal mechanism compatible with the activation of a NNE- or WNW-striking fault (Alvarado et al., 2009). Both fault planes are consistent with the orientation of regional fault trends in the area (Fig. 3A), but with the existing data it is not possible to discriminate between the two possible solutions (Alvarado et al., 2009). In the southern part of the studied Andean segment, in the area located towards the west of the 


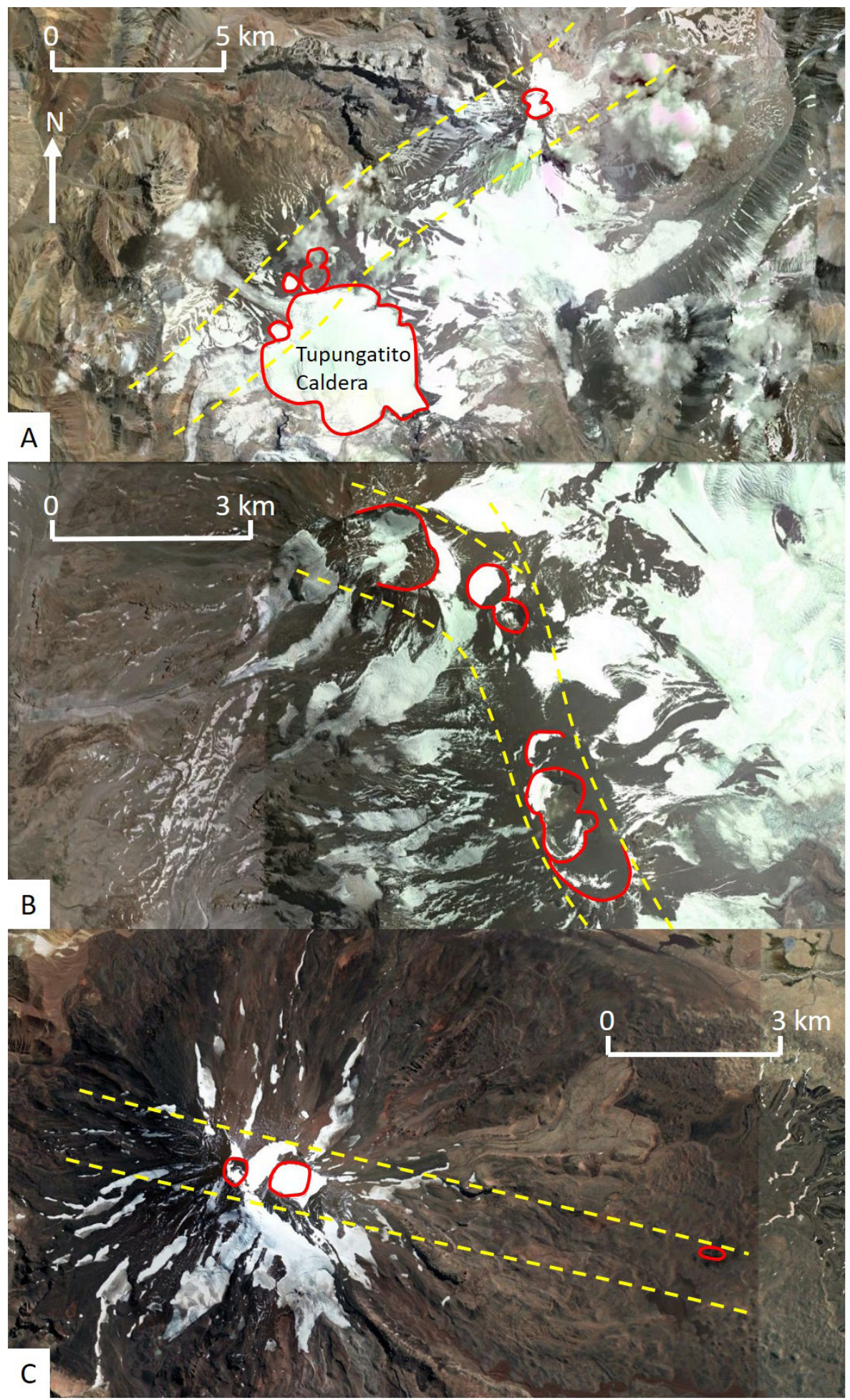

FIG. 5. Alignment of individual eruptive vents in the three active volcanic centers of central Chile. Satellite images from Google Earth. A. Tupungato-Tupungatito volcanic complex. B. San José volcano. C. Maipo volcano. 


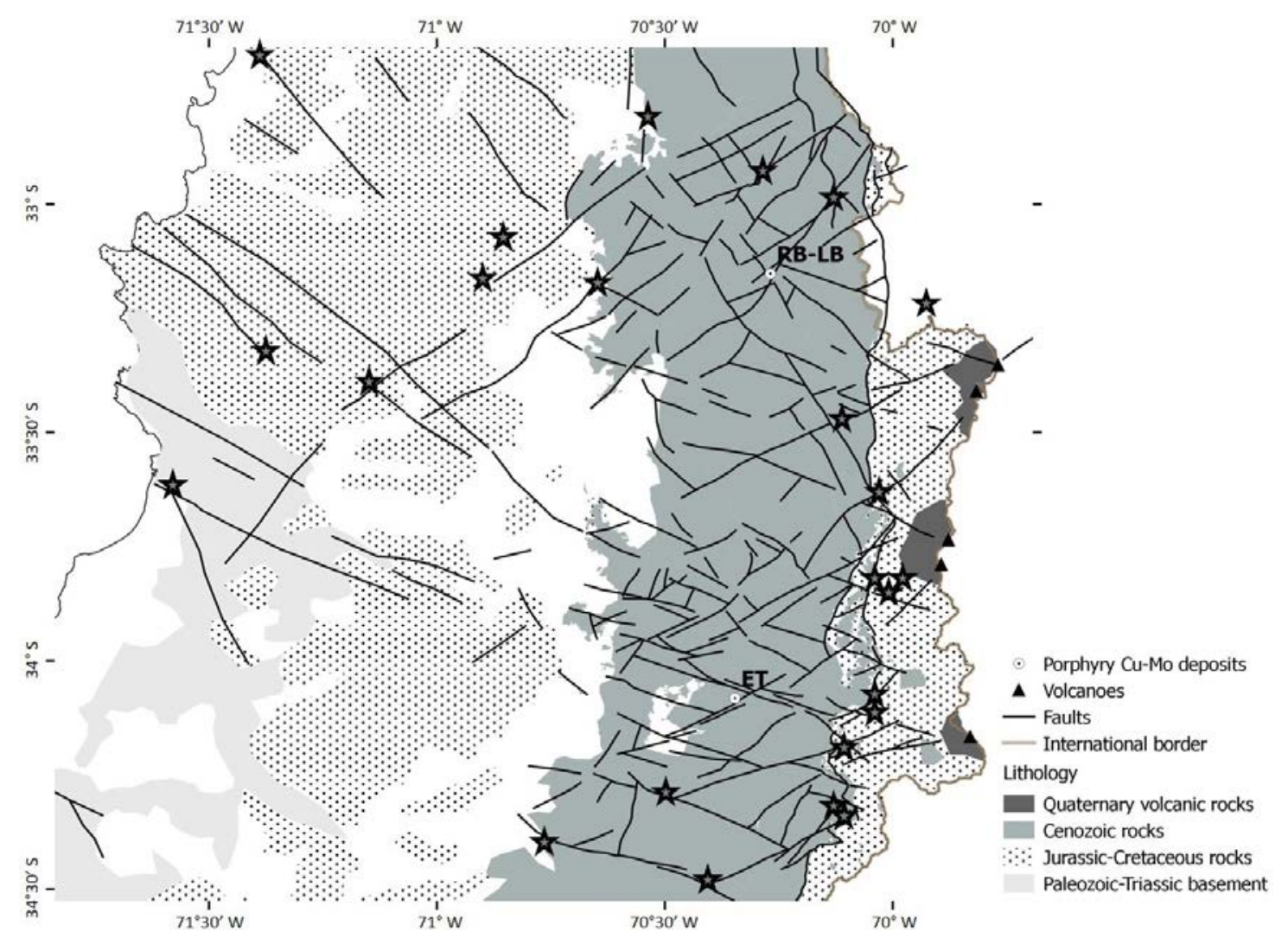

FIG. 6. Distribution of thermal springs, represented by stars, shown over a simplified version of the geological map of central Chile (from SERNAGEOMIN, 2002, and this work). Thermal occurrences from the compilation of Benavente et al. (2012) and personal field observations of the first author.

El Teniente porphyry Cu-Mo deposit, seismic clusters are also observed at the intersections between major arc-oblique fault systems and the NNE-striking, $\mathrm{W}$-vergent reverse faults cropping out at the inverted western margin of the Abanico basin (Barahona-Perales fault system of Rivera, 2017; Fig. 3A). Neotectonic activity of arc-oblique structures within the study area has been demonstrated by Lavenu and Cembrano (2008). They showed that Quaternary terraces of the Maipo river have been faulted and folded by NE and WNW-striking reverse faults, parallel to the trend of regional-scale faults recognized by this study (Fig. 7). This is relevant for the seismic hazard for the city of Santiago, as some parts of the city are located over the projection towards the west of major potentially active arc-oblique fault systems (Yáñez et al., 2015). As illustrated in figure 7, this is the case of both the El Salto fault (Piquer et al., 2015) and the Piuquencillo fault (Rivera and Falcón, 2000; Piquer et al., 2017).
All of the above have significant implications for mineral exploration in the area, and for the understanding of structural controls on active volcanism, geothermal systems and intra-plate earthquakes in this Andean segment. We interpret regional scale, strike-extensive but discontinuous arc-oblique fault systems to be reactivated basement structures, inherited from pre-Andean tectonic cycles: e.g., suture zones formed during accretion of continental blocks to the western margin of Gondwana in the Palaeozoic, and basin-margin and transfer faults active during Triassic rifting events (Charrier et al., 2015). These oblique fault systems are well developed in the basement of the Andes. They have been identified in the Coastal Cordillera of central Chile (Fig. 7), where NW-striking faults played a first-order role in controlling the ascent and emplacement of syn-tectonic early Mesozoic plutons and dike swarms (Gana and Zentilli, 2000; Creixell 


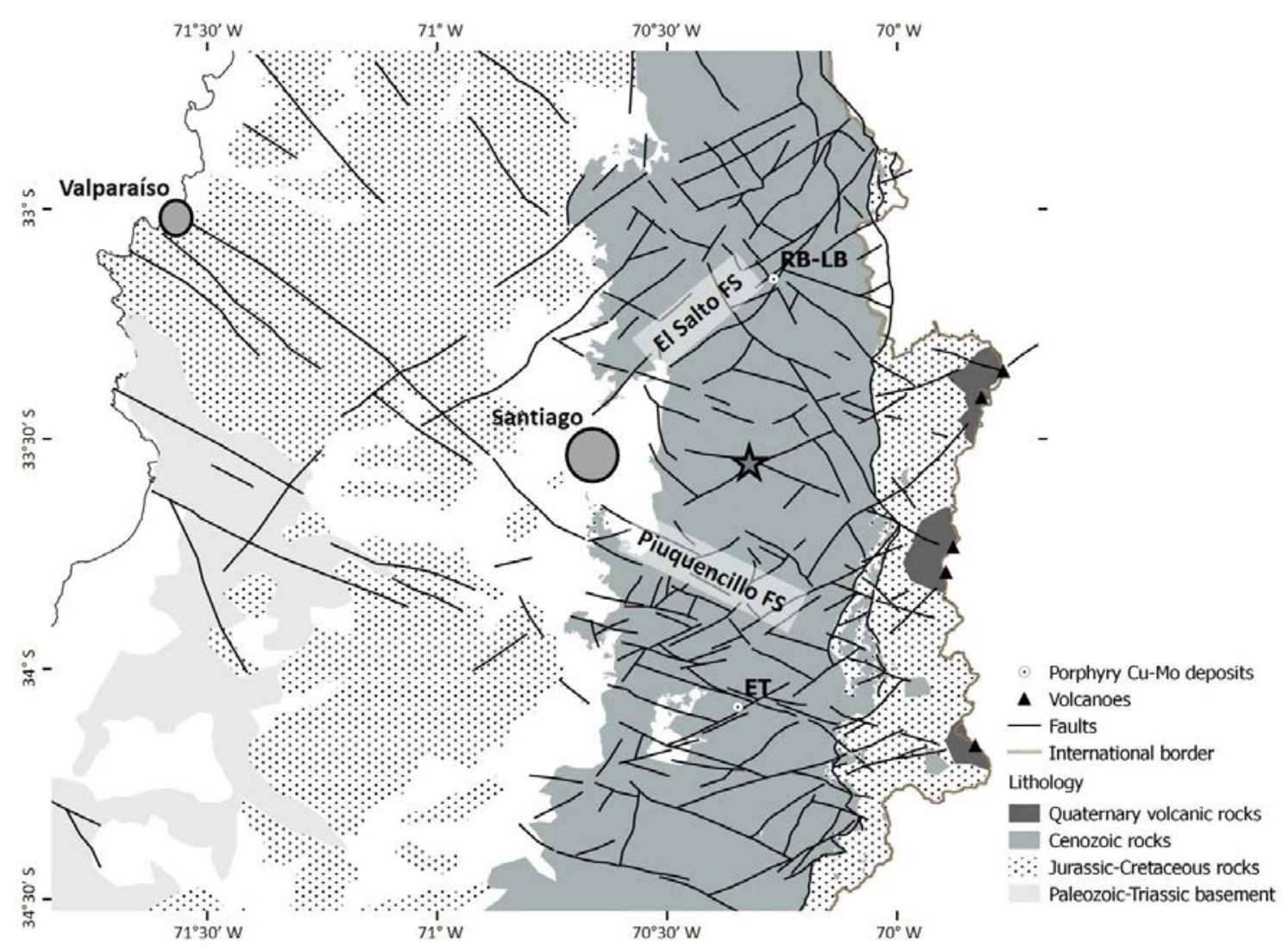

FIG. 7. Position of the regional-scale Piuquencillo and El Salto fault systems in relation to the city of Santiago. The star marks the locality studied by Lavenu and Cembrano (2008) with Quaternary terraces affected by NE- and WNW-striking reverse faults. Background geology simplified from SERNAGEOMIN (2002) and this work.

et al., 2011). Similar arc-oblique fault systems have been recognized in basement blocks cropping out in the Andes of northern Chile (Niemeyer et al., 2004), where NW-striking faults also played an important role for the emplacement of porphyry Cu-Mo deposits (Richards et al., 2001). NW- and NE-striking faults have also been studied in the Argentinean basement to the east (Salfity, 1985; Chernicoff et al., 2002; Acocella et al., 2011; Sagripanti et $a l .$, 2014). These high-angle, long-lived basement structures, and in particular their intersections, constitute major weakness and high-permeability zones, which have focused the ascent of magma through the brittle upper crust (Figs. 8, 9). Individual fault planes within these long-lived fault systems may be partially "sealed" by hydrothermal fluids or magma. However, as other fault segments and secondary faults will not be sealed, the fault systems as a whole will continue to act as lithospheric-scale weakness and permeability domains. Moreover, even an individual plane which has been "sealed" can be reactivated thousands of times, under a high fluid-flux regime, in repeated cycles of sealing and slip/opening (Sibson, 1990; Cox, 2016). This occurs because the contacts of veins and dikes emplaced along faults still constitute weakness planes which tend to accommodate subsequent fault ruptures and hydrothermal fluid or magmatic flow.

Field evidence for these long-lived, arc-oblique structures can be subtle where they have been covered by Meso-Cenozoic rocks and overprinted by more obvious, recent arc-parallel faults. In the high Andes of central Chile, with its continuous deposition of Cenozoic volcanic and sedimentary products, basement structures can manifest as small-displacement, discontinuous fault systems, as the fault has to propagate upwards through the younger rocks (Fig. 9). But as we show here, they 
can still be traced across the orogenic belt (Figs. 1,3) by a combination of structural, stratigraphic and geophysical methods. This type of fundamental basement structures, typically orogen-oblique and difficult to recognize in the field, are a critical element for ore genesis in magmatic and magmatichydrothermal ore deposits (Fig. 9; McCuaig and Hronsky, 2014).

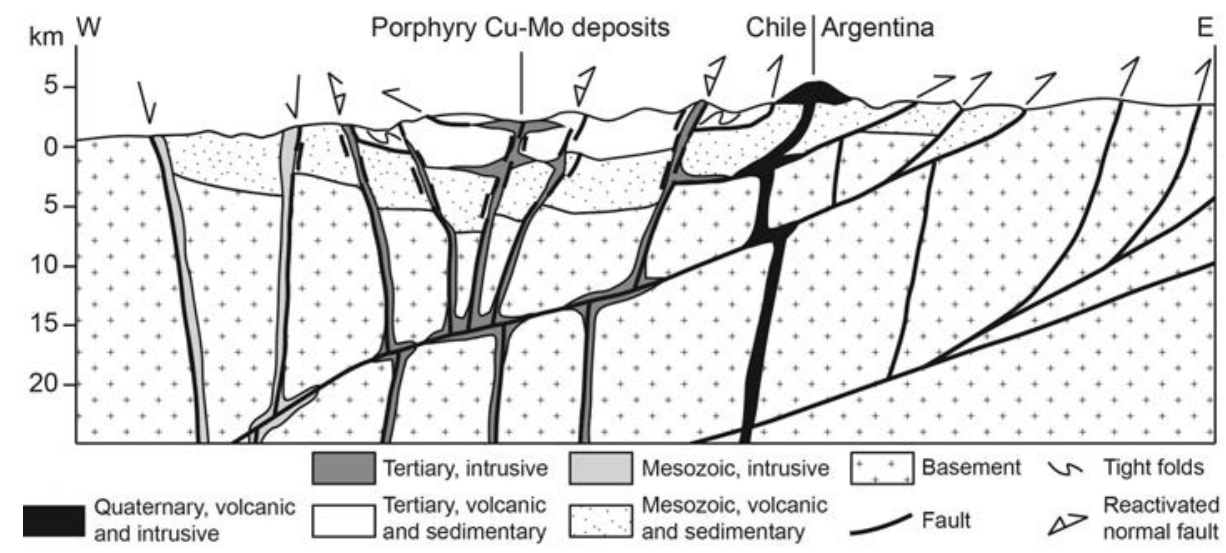

FIG. 8. Schematic W-E cross-section of the upper crust across the Andes of central Chile and Argentina, illustrating the complex interaction between high-angle, arc-oblique, basement-inherited faults and low-angle, arc-parallel thrusts formed during Andean orogenesis. High-angle oblique faults have played a prominent role channeling magmatism through the upper crust in the Mesozoic, Cenozoic and Quaternary magmatic arcs. Geology of the eastern flank of the Andes and geometry of the main thrusts based on Giambiagi et al. (2003).

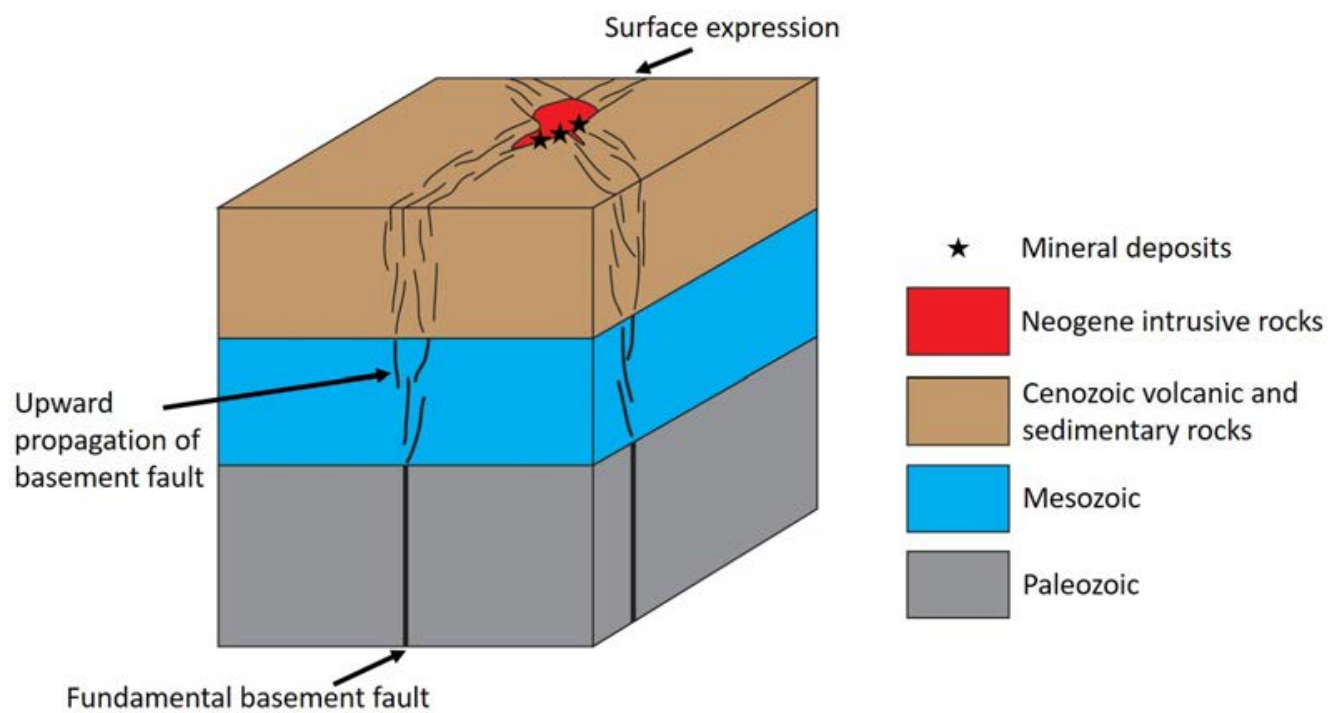

FIG. 9. Schematic diagram showing how fundamental basement faults propagate upwards trough younger rocks, being represented at the current surface by a network of minor faults, often difficult to recognize in the field. The diagram also illustrates the relationship between the intersections of fundamental basement faults and the emplacement of intrusive complexes and mineral deposits. Adapted from figure 7 of McCuaig and Hronsky (2014). 


\section{Conclusions}

A combination of structural and stratigraphic data and the analysis of large-scale geophysical studies allowed us to interpret the relationship between the regional-scale structural architecture of the inverted Abanico Basin and the emplacement of intrusive bodies, volcanic centers, hydrothermal systems and the patterns of upper-crustal seismicity. Existing geological and geophysical data indicate that the internal architecture of the inverted basin is dominated by NE- and NW-striking faults, which we interpret as reactivated weakness zones inherited from the pre-existing structural architecture of the Andean basement. Some fault systems bound regional-scale gravimetric domains, suggesting that they define the deep architecture of the crust beneath the high Andes. During the Meso-Cenozoic, basement faults were reactivated with different kinematics according to the prevailing stress tensor, and they were propagated vertically through the Mesozoic and Cenozoic volcanic and sedimentary cover. This can explain why in the Cenozoic rocks of the Andes of central Chile, continental-scale faults which are interpreted to control the rise of magma through the upper crust are represented at the current surface only by minor faults with small (metric) displacements. During the early Miocene to early Pliocene, in particular, arcoblique faults were active as conjugate strike-slip faults with minor reverse components, consistent with broadly E-directed compression. During this period, they separated packages of volcanic rocks with contrasting deformation styles. The intersection zones of conjugate, arc-oblique, regional-scale fault systems correspond to areas of maximum damage and enhanced permeability, and are strongly related to the distribution of Miocene intrusive bodies, late Miocene-early Pliocene porphyry $\mathrm{Cu}-\mathrm{Mo}$ deposits, active volcanic centers and their eruptive vents, the location of thermal springs and the position of clusters of upper-crustal seismicity, showing that they are being reactivated under the current stress regime.

By combining field-based structural geology with regional-scale geophysics, major oblique fault systems can be identified even where they have been obscured by young volcanic and sedimentary deposits and/or arc-parallel structures. This approach can be applied to other Andean segments and to orogenic belts elsewhere, leading to improved exploration models for subduction-related mineral deposits and also to a better understanding of the structural controls on volcanism, geothermal activity and crustal seismicity.

\section{Acknowledgments}

Part of this work is the result of a Ph.D. study by the first author at the University of Tasmania, which was supported by a Becas Chile scholarship from Conicyt and by research funding from the AMIRA P1060 project "Enhanced Geochemical Targeting in Magmatic-Hydrothermal Systems". CODELCO and all the sponsors of the AMIRA P1060 project are acknowledged for allowing the publication of this work. The field campaigns of 2016 and 2017 were part of an internal research project of Universidad Austral de Chile, project DID S-2016-32 "El Sistema de Falla Piuquencillo: evolución y control sobre el emplazamiento de sistemas hidrotermales". Most of the hypocenter location data used in this work was captured during the Ring Project ACT $\mathrm{N}^{\circ} 18$ carried out by Universidad de Chile and CODELCO.

We thank Dr. V. Maksaev and Dr. J. Skármeta for their careful review of our manuscript, which greatly improved its quality.

\section{References}

Acocella, V.; Gioncada, A.; Omarini, R.; Riller, U.; Mazzuoli, R.; Vezzoli, L. 2011. Tectonomagmatic characteristics of the back-arc portion of the CalamaOlacapato-El Toro Fault Zone, Central Andes. Tectonics 30: TC3005. doi: 10.1029/2010TC002854.

Aguirre, L. 1960. Geología de los Andes de Chile Central, Provincia de Aconcagua. Instituto de Investigaciones Geológicas 9: $70 \mathrm{p}$.

Alvarado, P.; Barrientos, S.; Sáez, M.; Astroza, M.; Beck, S. 2009. Source study and tectonic implications of the historic 1958 Las Melosas crustal earthquake, Chile, compared to earthquake damage. Physics of the Earth and Planetary Interiors 175 (1-2): 26-36.

Amilibia, A.; Sabat, F.; McClay, K.R.; Muñoz, J.A.; Roca, E.; Chong, G. 2008. The role of inherited tectono-sedimentary architecture in the development of the central Andean mountain belt: Insights from the Cordillera de Domeyko. Journal of Structural Geology 30: 1520-1539.

Baeza, O. 1999. Análisis de litofacies, evolución depositacional y análisis estructural de la Formación Abanico en el área comprendida entre los ríos Yeso y Volcán, Región Metropolitana. Memoria de Título (Inédito), Universidad de Chile: 119 p. 
Benavente, O.; Aguilera, F.; Gutiérrez, F.; Tassi, F.; Reich, M.; Vaselli, O. 2012. Los sistemas hidrotermales de Chile Central (33-36 ${ }^{\circ}$ ). In Congreso Geologico Chileno, No. 13, Actas: 559-561. Antofagasta.

Cembrano, J.; Lara, L. 2009. The link between volcanism and tectonics in the southern volcanic zone of the Chilean Andes: A review. Tectonophysics 471: 96-113.

Charrier, R.; Baeza, O.; Elgueta, S.; Flynn, J.J.; Gans, P.; Kay, S.M.; Muñoz, N.; Wyss, A.R.; Zurita, E. 2002. Evidence for Cenozoic extensional basin development and tectonic inversion south of the flat-slab segment,

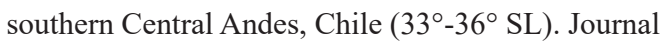
of South American Earth Sciences 15 (1): 117-139.

Charrier, R.; Ramos, V.A.; Tapia, F.; Sagripanti, L. 2015. Tectono-stratigraphic evolution of the Andean Orogen between 31 and $37^{\circ} \mathrm{S}$ (Chile and Western Argentina). In Geodynamic Processes in the Andes of Central Chile and Argentina (Sepúlveda, S.A.; Giambiagi, L.; Moreiras, S.M.; Pinto, L.; Tunik, M.; Hoke, G.D.; Farías, M.; editors). Geological Society, Special Publication 399. doi: 10.1144/SP399.20. London.

Chernicoff, C.; Richards, J.; Zappettini, E. 2002. Crustal lineament control on magmatism and mineralization in northwestern Argentina: geological, geophysical and remote sensing evidence. Ore Geology Reviews 21: 127-155.

Cox, S.F. 2016. Injection-Driven Swarm Seismicity and Permeability Enhancement: Implications for the Dynamics of Hydrothermal Ore Systems in High Fluid-Flux, Overpressured Faulting Regimes-An Invited Paper. Economic Geology 111: 559-587.

Creixell, C.; Parada, M.A.; Morata, D.; Vásquez, P.; Pérez de Arce, C.; Arriagada, C. 2011. Middle-Late Jurassic to Early Cretaceous transtension and transpression during arc building in Central Chile: evidence from mafic dike swarms. Andean Geology 38 (1): 37-63. doi: 10.5027/andgeoV38n1-a04.

Deckart, K.; Clark, A.; Cuadra, P.; Fanning, M. 2013. Refinement of the time-space evolution of the giant Mio-Pliocene Río Blanco-Los Bronces porphyry $\mathrm{Cu}-$ Mo cluster, Central Chile: new U-Pb (SHRIMP II) and Re-Os geochronology and ${ }^{40} \mathrm{Ar} /{ }^{39} \mathrm{Ar}$ thermochronology data. Mineralium Deposita 48: 57-79.

Farías, M.; Comte, D.; Charrier, R.; Martinod, J.; David, C.; Tassara, A.; Tapia, F., Fock, A. 2010. Crustal-scale structural architecture in central Chile based on seismicity and surface geology: Implications for Andean mountain building. Tectonics 29: TC3006. doi: 10.1029/2009TC002480.

Fock, A. 2005. Cronología y tectónica de la exhumación en el Neógeno de los Andes de Chile Central entre los $33^{\circ}$ y los $34^{\circ} \mathrm{S}$. Memoria de Título (Inédito), Universidad de Chile, Departamento de Geología: 179 p.

Fuentes, F.; Vergara, M.; Aguirre, L.; Feraud, G. 2002. Contact relationships of Tertiary volcanic units from the Andes of central Chile $\left(33^{\circ} \mathrm{S}\right)$ : a reinterpretation based on ${ }^{40} \mathrm{Ar} /{ }^{39} \mathrm{Ar}$ dating. Revista Geológica de Chile 29: 207-225. doi: 10.5027/andgeoV29n2-a04.

Fuentes, F.; Aguirre, L.; Vergara, M.; Valdebenito, L.; Fonseca, E. 2004. Miocene fossil hydrothermal system associated with a volcanic complex in the Andes of central Chile. Journal of Volcanology and Geothermal Research 138: 139-161.

Gana, P.; Zentilli, M. 2000. Historia termal y exhumación de intrusivos de la Cordillera de la Costa de Chile Central. In Congreso Geológico Chileno, No. 9, Actas 2: 664-668. Puerto Varas.

Giambiagi, L.B.; Ramos, V.A.; Godoy, E.; Álvarez, P.P.; Orts, S. 2003. Cenozoic deformation and tectonic style of the Andes, between $33^{\circ}$ and $34^{\circ}$ SL. Tectonics 22 (4): TC1041. doi: 10.1029/2001TC001354.

Godoy, E. 1993. Geología del área entre los ríos Claro del Maipo y Cachapoal. CODELCO ChileSERNAGEOMIN: 68 p. Santiago.

Godoy, E.; Yáñez, G.; Vera, E. 1999. Inversion of an Oligocene volcano-tectonic basin and uplifting of its superimposed Miocene magmatic arc in the Chilean Central Andes: first seismic and gravity evidences. Tectonophysics 306: 217-236.

Hodgson, C.J. 1989. The structure of shear-related, vein-type gold deposits: a review. Ore Geology Reviews 4: 231-273.

Horsfield, W.T. 1980. Contemporaneous movement along crossing conjugate normal faults. Journal of Structural Geology 2 (3): 305-310.

Kay, S.M.; Godoy, E.; Kurtz, A. 2005. Episodic arc migration, crustal thickening, subduction erosion, and magmatism in the south-central Andes. Geological Society of America Bulletin 117: 67-88. doi: 10.1130/ B25431.1.

Klohn, C. 1960. Geología de la Cordillera de los Andes de Chile Central. Instituto de Investigaciones Geológicas, Boletín 8: 95 p.

Lavenu,A.; Cembrano, J. 2008. Quaternary compressional deformation in the Main Cordillera of Central Chile (Cajón del Maipo, east of Santiago). Revista Geológica deChile 35:233-252. doi: 10.5027/andgeoV35n2-a03.

Leveille, R.A.; Stegen, R.J. 2012. The Southwestern North America Porphyry Copper Province. Society of Economic Geologists, Special Publication 16: 361-401. 
Maksaev, V.; Munizaga, F.; McWilliams, M.; Fanning, M.; Mathur, R.; Ruiz, J.; Zentilli, M. 2004. New chronology for El Teniente, Chilean Andes, from $\mathrm{U}-\mathrm{Pb},{ }^{40} \mathrm{Ar} /{ }^{39} \mathrm{Ar}$, $\mathrm{Re} / \mathrm{Os}$ and fission-track dating: Implications for the evolution of a supergiant porphyry Cu-Mo deposit. Society of Economic Geologists, Special Publication 11: 15-54.

McCuaig, T.C.; Hronsky, J.M.A. 2014. The mineral system concept: the key to exploration targeting. Society of Economic Geologists, Special Publication 18: 153-176.

Mpodozis, C.; Cornejo, P. 2012. Cenozoic tectonics and porphyry copper systems of the Chilean Andes. Society of Economic Geologists, Special Publication 16: 329-360.

Niemeyer, H.; Berríos, H.; Ruiz, M. 2004. Temperatures of formation in Triassic cataclasites of Cordillera Domeyko, Antofagasta, Chile. Revista Geológica de Chile 31 (1): 3-18. doi: 10.4067/S0716-02082004000100001.

Pardo, M.; Vera, E.; Monfret, T.; Yáñez, G. 2008. Crustal seismicity and $3 \mathrm{D}$ seismic wave velocity models in the Andes cordillera of Central Chile $\left(33^{\circ}-34.5^{\circ} \mathrm{S}\right)$ from local earthquakes. In International Symposium on Andean Geodynamics, No. 7, Actas: 377-380. Nice.

Perelló, J.; Carlotto, V.; Zárate, A.; Ramos, P.; Posso, H.; Neyra, C.; Caballero, A.; Fuster, N.; Muhr, R. 2003. Porphyry-Style Alteration and Mineralization of the Middle Eocene to Early Oligocene AndahuaylasYauri Belt, Cuzco Region, Peru. Economic Geology 98: 1575-1605.

Pérez-Flores, P.; Cembrano, J.; Sánchez-Alfaro, P.; Veloso, E.; Arancibia, G.; Roquer, T. 2016. Tectonics, magmatism and paleo-fluid distribution in a strike-slip setting: Insights from the northern termination of the Liquiñe-Ofqui fault System, Chile. Tectonophysics 680: 192-210.

Piquer, J.; Castelli, J.C.; Charrier, R.; Yánez, G. 2010. The Cenozoic of the upper Teno River, Cordillera Principal, central Chile: stratigraphy, plutonism and their relation with deep structures. Andean Geology 37: 32-53.

Piquer, J.; Skármeta, J.; Cooke, D.R. 2015. Structural evolution of the Río Blanco-Los Bronces district, Andes of central Chile: controls on stratigraphy, magmatism and mineralization. Economic Geology 110: 1995-2023.

Piquer, J.; Berry, R.F.; Scott, R.J.; Cooke, D.R. 2016. Arc-oblique fault systems: their role in the Cenozoic structural evolution and metallogenesis of the Andes of central Chile. Journal of Structural Geology 89: 101-117.
Piquer, J.; Hollings, P.; Rivera, O.; Cooke, D.R.; Baker, M.; Testa, F. 2017. Along-strike segmentation of the Abanico Basin, central Chile: new chronological, geochemical and structural constraints. Lithos 268: 174-197.

Richards, J.P.; Boyce, A.J.; Pringle, M.S. 2001. Geologic evolution of the Escondida area, northern Chile: A model for spatial and temporal localization of porphyry $\mathrm{Cu}$ mineralization. Economic Geology 96: 271-305.

Rivera, O. 2017. Marco geodinámico para los pórfidos cupríferos Mio-Pliocenos de Chile central: rol de estructuras translitosféricas y anomalías gravimétricas en la metalogénesis Andina. Master's Thesis (Unpublished), Universidad Católica del Norte: 214 p.

Rivera, O.; Cembrano, J. 2000. Modelo de formación de cuencas volcano-tectónicas en zonas de transferencia oblicuas a la cadena andina: el caso de las cuencas Oligo-Miocenas de Chile Central y su relación con estructuras NWW-NW (3300'-34³0' LS). In Congreso Geológico Chileno, No. 9, Actas: 631-636. Puerto Varas.

Rivera, O.; Falcón, M.F. 2000. Secuencias de relleno de cuencas volcano-tectónicas transversales OligoMiocenas en los alrededores del yacimiento El Teniente (334' '-34³0' LS). In Congreso Geológico Chileno, No. 9, Actas: 819-823. Puerto Varas.

Rivera, O.; Cerda, A. 2012. Los Pórfidos Cupríferos de Chile Central: significado de estructuras translitosféricas y anomalías gravimétricas en la metalogénesis Andina. In Congreso Geológico Chileno, No. 13, Actas: 2-4. Antofagasta.

Sagripanti, L.; Folguera, A.; Giménez, M.; Rojas Vera, E.A.; Fabiano, J.J.; Molnar, N.; Fennell, L.; Ramos, V.A. 2014. Geometry of Middle to Late Triassic extensional deformation pattern in the Cordillera del Viento (Southern Central Andes): A combined field and geophysical study. Journal of Iberian Geology 40 (2): 349-366.

Salfity, J.A. 1985. Lineamientos transversales al rumbo andino en el noroeste argentino. In Congreso Geológico Chileno, No. 4, Actas 2: 119-137. Antofagasta.

Sánchez, P.; Pérez-Flores, P.; Arancibia, G.; Cembrano, J.; Reich, M. 2013. Crustal deformation effects on the chemical evolution of geothermal systems: the intraarc Liquiñe-Ofqui fault system, Southern Andes. International Geology Review 55: 1384-1400.

Schwarz, H.U.; Kilfitt, F.W. 2008. Confluence and intersection of interacting conjugate faults: a new concept based on analogue experiments. Journal of Structural Geology 30: 1126-1137. doi: 10.1016/j. jsg.2008.05.005. 
Sepúlveda, S.; Astroza, M.; Kausel, E.; Campos, J.; Casas, E.; Rebolledo, S.; Verdugo, R. 2008. New findings on the 1958 Las Melosas earthquake sequence, Central Chile: Implications for seismic hazard related to shallow crustal earthquakes in subduction zones. Journal of Earthquake Engineering 12: 432-455.

SERNAGEOMIN. 2002. Mapa Geológico de Chile 1:100.000. Servicio Nacional de Geología y Minería, Carta Geológica de Chile, Serie Geología Básica 75, 1 mapa en 3 hojas.

Sibson, R.H. 1990. Conditions for fault-valve behavior. In Deformation Mechanisms, Rheology and Tectonics (Knipe, R.J.; Rutter, E.H.; editors). Geological Society, Special Publication 54: 15-28. London.

Sielfeld, G.; Cembrano, J.; Lara, L. 2017. Transtension driving volcano-edifice anatomy: Insights from Andean transverse-to-the-orogen tectonic domains. Quaternary International 438 (A): 33-49. doi: 10.1016/j. quaint.2016.01.002.

Sillitoe, R.H. 2003. Iron oxide-copper-gold deposits: an Andean view. Mineralium Deposita 38: 787-812.

Sillitoe, R.H. 2010. Porphyry copper systems. Economic Geology 105: 3-41.

Sillitoe, R.H.; Perelló, J. 2005. Andean Copper Province: Tectonomagmatic Settings, Deposit Types, Metallogeny, Exploration, and Discovery. Economic Geology 100: 845-890.

Tibaldi, A.; Bonali, F.L.; Corazzato, C. 2017. Structural control on volcanoes and magma paths from local- to orogen-scale: The central Andes case. Tectonophysics 699: 16-41.

Toro, J.C.; Ortúzar, J.; Zamorano, J.; Cuadra, P.; Hermosilla, J.; Sprohnle, C. 2012. Protracted magmatichydrothermal history of the Río Blanco-Los Bronces district, Central Chile: Development of world's greatest known concentration of copper. Society of Economic Geologists Special Publication 16: 105-126.

Tosdal, R.; Richards, J.P. 2001. Magmatic and structural controls on the development of porphyry $\mathrm{Cu}+\mathrm{Mo}+\mathrm{Au}$ deposits. In Structural controls on ore genesis (Richards, J.P.; Tosdal, R.; editors). Society of Economic Geologists, Reviews in Economic Geology 14: 157-181.

Yáñez, G.; Rivera, O. 2009. Geophysical constraints of the Mapocho El Volcán block (MEV-b), and its geological significance. In Congreso Geológico Chileno, No. 12, Actas: 4 p. Santiago.

Yáñez, G.; Rivera, O.; Comte, D.; Pardo, M.; Baeza, L.; Vera, E. 2008. Damage zones and the occurrence of world-class porphyry copper deposits in the active margin of Chile: Geophysical signatures and tectonomagmatic inferences. In International Symposium on Andean Geodynamics, No. 7, Actas: 592-593. Nice.

Yáñez, G.; Muñoz, M.; Flores-Aqueveque, V.; Bosh, A. 2015. Gravity derived depth to basement in Santiago Basin, Chile: implications for its geological evolution, hydrogeology, low enthalpy geothermal, soil characterization and geo-hazards. Andean Geology 42: 147-172. doi: 10.5027/andgeoV42n2-a01.

Manuscript received: August 29, 2017; revised/accepted: September 20, 2018; available online: January 31, 2019.

Editorial handling: Jorge Skármeta M. 